\title{
Substantial open-ocean phytoplankton blooms to the north of South Georgia, South Atlantic, during summer 1994
}

\author{
M. J. Whitehouse*, J. Priddle, P. N. Trathan, M. A. Brandon \\ British Antarctic Survey, NERC, High Cross, Madingley Road, Cambridge CB3 0ET, United Kingdom
}

\begin{abstract}
Substantial open-ocean phytoplankton blooms in the Antarctic Zone to the northwest of South Georgia, South Atlantic are described. Chlorophyll $a$, nutrient and physical oceanography data, collected between 2 and 5 January 1994 and again 1 mo later between 2 and 4 February along a $450 \mathrm{~km}$ transect comprising 14 stations, are presented. The transect crossed the Subantarctic and the Polar Front. During the January transect survey, in 2 locations to the south of the Polar Front, average surface mixed-layer chlorophyll a concentrations were $>8$ and $>13 \mathrm{mg} \mathrm{m}^{-3}$, and were associated with silicate, nitrate and phosphate depletions $\left(<2.0,<11.0\right.$ and $1.0 \mathrm{mmol} \mathrm{m}{ }^{-3}$ respectively), and nitrite and ammonium enhancement ( $>0.3$ and $>1.4 \mathrm{mmol} \mathrm{m}^{-3}$ respectively). One of the phytoplankton blooms was associated with the nearby Polar Front, but the origin of a bloom further south, well within the Antarctic Zone, was not clear. Phytoplankton production predicted by nutrient drawdown was far greater than the observed biomass on both surveys. If a common Antarctic Zone origin is accepted for the southern bloom, a decline in biomass of $\sim 2.7 \mathrm{~mol} \mathrm{C} \mathrm{m}^{-2}$ occurred in the upper $50 \mathrm{~m}$ of the water column between the 2 surveys, which cannot be accounted for by zooplankton grazing. If the bloom had originated in Subantarctic water advected to the south of the Polar Front, initial nutrient concentrations would have been lower and consequently predicted production was closer to the observed biomass values. Nevertheless, the area may be one of intense but local carbon export.
\end{abstract}

KEY WORDS: Phytoplankton blooms - Nutrents - Antarctic Zone Polar Front - South Atlantic Carbon export

\section{INTRODUCTION}

The open oceans of the Antarctic are generally regarded as areas of low phytoplankton productivity. Although several sites in the Scotia Sea have been identified as exceptions to this, overall chlorophyll a (chl a) levels in this region remain relatively low at $<2.5 \mathrm{mg} \mathrm{m}^{-3}$ (Rönner et al. 1983, Jacques 1989, Tréguer \& Jacques 1992). In some areas of the Antarctic a variety of features offer stable conditions in which elevated phytoplankton growth can occur. Receding pack ice may provide stable near-surface conditions, with low salinity melt water overlaying denser water, where chl a concentrations greater than $7 \mathrm{mg} \mathrm{m}^{-3}$ have been measured (Smith \& Nelson 1985, Nelson et al. 1987,

•E-mail: m.whitehouse@bas.ac.uk
1989, Jacques 1989, Cota et al. 1992). Similar concentrations have also been recorded in frontal zones that receive inputs of warmer water or nutrients, or that are seeded from upstream (Lutjeharms et al. 1985, Jacques \& Panouse 1991, Perissinotto et al. 1992, Boyd et al. 1995, Bury et al. 1995, Savidge et al. 1995, Whitehouse et al. 1995). However, by far the highest chlorophyll concentrations (up to $30 \mathrm{mg} \mathrm{m}^{-3}$ ) have been measured in neritic areas, associated with a variety of islandmass effects including water column stability and nutrient enrichment derived from island runoff (Heywood \& Priddle 1987, Boden 1988, Jacques 1989, Holm-Hansen \& Mitchell 1991, Perissinotto et al. 1992, Whitehouse et al. in press).

The isolated island of South Georgia lies in hydrographically complex and productive waters that support large populations of higher predators. It is situated on the North Scotia Ridge that runs from Burdwood 
Bank south of the Falkland Islands, east to the South Sandwich Islands. The Antarctic Circumpolar Current (ACC) in the vicinity of South Georgia comprises 3 latitudinal zones separated by 2 major fronts: from north to south the Subantarctic Zone (SAZ), the Subantarctic Front (SAF), the Polar Frontal Zone (PFZ), the Polar Front (PF) and the Antarctic Zone (AAZ). The ACC flows in a generally easterly direction, and the Scotia Arc forms a variable-height barrier to its progress as it flows out of the Scotia Sea, deflecting the main path of the current to the north across the North Scotia Ridge. Over the North Scotia Ridge the PF lies about equidistant between Burdwood Bank and South Georgia over Shag Rocks Passage, the only fracture greater than $3000 \mathrm{~m}$ in this section of the North Scotia Ridge. North of the North Scotia Ridge the ACC resumes an easterly course towards the Georgia Basin, to the north of South Georgia (Sievers \& Nowlin 1988, Peterson \& Whitworth 1989, Orsi et al. 1995).

Elevated phytoplankton concentrations $>20 \mathrm{mg} \mathrm{m}^{-3}$ have been measured in the seas around South Georgia, where they are usually recorded in relatively small-scale patches and have been attributed to interactions between different watermasses or to shelfbreak upwellings or accumulations [Hardy \& Gunther 1935. Hardy 1967. Whitehouse et al. 1993, in press, British Antarctic Survey (BAS) data]. During January 1994 elevated chl a concentrations $\left(14.3 \mathrm{mg} \mathrm{m}^{-3}\right.$ maximum) were recorded along parts of a $450 \mathrm{~km}$ transect to the northwest of South Georgia. Such high concentrations have rarely been reported in open ocean Antarctic waters. The chlorophyll distribution, which appeared to be associated with a region of nutrient depletion, suggested that 2 distinct blooms were present, both in deep water, south of the PF. In this paper, we document the chl a concentrations and the associated physico-chemical environment and we speculate on the mechanisms that may have facilitated the presence of such phytoplankton levels.

\section{METHODS}

During cruise JR06 of the RRS 'James Clark Ross', a $450 \mathrm{~km}$ transect, comprising 14 CTD stations sited $-35 \mathrm{~km}$ apart, was surveyed between 2 and 5 January and again between 2 and 4 February 1994 (Fig. 1). The first survey along the transect (T02) ran northwestsoutheast, and the second (T74) southeast-northwest, between $50^{\circ} 00^{\prime} \mathrm{S}, 42^{\circ} 00^{\prime} \mathrm{W}$ above the Maurice Ewing Bank (MEB) and $53^{\circ} 36^{\prime} \mathrm{S}, 38^{\circ} 54^{\prime} \mathrm{W}$ some $80 \mathrm{~km}$ from the northwest tip of South Georgia.

At each station a Neil Brown Mk III CTD equipped with twelve $10 \mathrm{l}$ water bottles on a sampling rosette was used to measure hydrographic structure. The

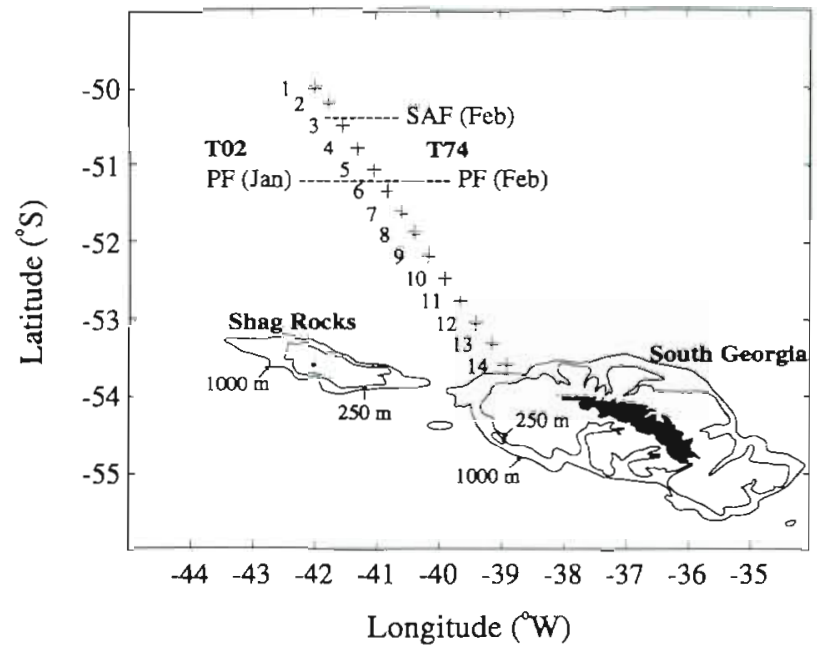

Fig. 1. Station positions along transects T02 and T74 including the positions of the Polar Front (PF) and Subantarctic Front (SAF) to the northwest of South Georgia, and the locations of Shag Rocks and the 250 and $1000 \mathrm{~m}$ isobaths

depth of the CTD casts varied according to bathymetry, but all were to at least $1000 \mathrm{~m}$ with intermittent casts to near bottom. Water bottle samples were collected at $10,20,40,60,100$ and $200 \mathrm{~m}$, as well as at 6 additional depths between $200 \mathrm{~m}$ and the bottom of the cast. Density properties from each CTD cast were used to determine the surface mixed-layer depth to the nearest $5 \mathrm{~m}$.

Sub-samples from the water bottle samples collected between 10 and $200 \mathrm{~m}$ were filtered through a glass fibre filter (Whatman GF/F, pore size $0.7 \mu \mathrm{m}$ ), and the retained particulate material was analysed for chlorophyll and phaeopigments (Parsons et al. 1984). Filters were extracted in $90 \%$ acetone and the fluorescence of the extract was measured before and after acidification using a Sequoia Turner 112 fluorometer, calibrated with commercially prepared chl a (Sigma Chemical Company, St. Louis, MO, USA). Further sub-samples from all water bottles were filtered through a mixed ester membrane (Whatman WME, pore size $0.45 \mu \mathrm{m}$ ) and the filtrate was analysed colorimetrically for dissolved nutrients using a Technicon segmented flow analyser. All water bottle samples were analysed for nitrate $\left(\mathrm{NO}_{3}+\mathrm{NO}_{2}-\mathrm{N}\right)$, nitrite $\left(\mathrm{NO}_{2}-\mathrm{N}\right)$, ammonium $\left(\mathrm{NH}_{4}-\mathrm{N}\right)$ and silicate $\left[\mathrm{Si}(\mathrm{OH})_{4}-\mathrm{Si}\right]$, and in addition the transect $\mathrm{T} 74$ water samples were analysed for phosphate $\left(\mathrm{PO}_{4}-\mathrm{P}\right)$ (Whitehouse \& Woodley 1987).

During the cruise, remotely sensed AVHRR images of sea surface temperature data were obtained (via the BAS receiving station at Rothera, Adelaide Island, Antarctic Peninsula) from NOAA polar orbiting satellites using infrared sensors operating at $11 \mu \mathrm{m}$. Images were obtained that included information from cloudfree areas of the PFZ to the north and west of South 
Georgia, and transformed to a standard polar stereographic projection in order to aid interpretation.

The SYSTAT statistics package (Wilkinson et al. 1992) was used to measure significant variation (1-way ANOVA) and simple Pearson correlations between average chl a concentrations and physical and nutrient values in the surface mixed-layer (SML), and to extract descriptive summary statistics.

\section{RESULTS}

\section{Physical oceanography}

A well defined PF was evident along both transects (Fig. 2). The 5 northernmost stations of transect T02 were situated in the PFZ, whereas the remaining 9 stations were located south of the PF in AAZ waters (P. N. Trathan, M. A. Brandon \& E. J. Murphy unpubl.). Between the 2 surveys of the transect the position of the SAF shifted southwards so that the 2 northernmost stations of transect T74 were located in the SAZ. The location of the PF moved little in the intervening period $\left(\sim 0.5^{\circ}\right.$ of latitude south), so that Stns 3 to 5 remained in PFZ water and the 9 southernmost stations in the AAZ.

Overall the surface water temperature had increased by $\sim 1.0^{\circ} \mathrm{C}$ between transects T02 and T74 (Table 1). Surface waters were well mixed to a depth of $\sim 50 \mathrm{~m}$ during both transects, with shallower SML at Stns 1 and 5 during transect T02, and deeper mixing evident at Stn 13 during transect T02 and Stn 12 during transect T74 (Table 1).

The CTD profiles provided no evidence of mesoscale features such as core rings or meanders at the major fronts along either of the transect surveys (Trathan et al. unpubl.). However, calculated geostrophic flows at $200 \mathrm{~m}$ referenced to $1000 \mathrm{~m}$ revealed a well-defined frontal jet of $16 \mathrm{~cm} \mathrm{~s}^{-1}$ between Stns 5 and 6 . Between the PF and South Georgia, Trathan et al. (unpubl.) identified 2 separate surface water regimes based on the temperature/salinity $(\mathrm{T} / \mathrm{S})$ structure at the nearsurface temperature minima. They suggested that one regime represented the easterly flowing $A C C$, and the other a colder and more saline water, flowing west along the coast of South Georgia. They also showed spatial and temporal variability in the position of the boundary between the 2 regimes.

The South Georgia area is often cloud-covered and there are very few cloud-free days coincident with AVHRR imagery. However, an image with substantial cloud-free areas was obtained which covered the region to the north and west of South Georgia, including the area covered by the present study, during the transect T74 survey (Fig. 3). A cold area was apparent to the north of South Georgia itself, where a very strong temperature gradient marked the PF which appeared as a series of bands each with differing surface temperatures. To the southwest of Shag Rocks there was a warm-water protrusion from the PF, and to the south of Shag Rocks there were several eddy-like features which appeared to be moving in the eastward flow of the ACC.

\section{Chl $a$ and phaeopigments}

Chl a concentrations greater than $1.0 \mathrm{mg} \mathrm{m}^{-3}$ were confined to the top $100 \mathrm{~m}$ of the water column, generally within the surface mixed-layer (Fig. 4). Along tran-
Fig. 2. Temperature $\left({ }^{\circ} \mathrm{C}\right)$ and salinity sections along transects T02 and T74

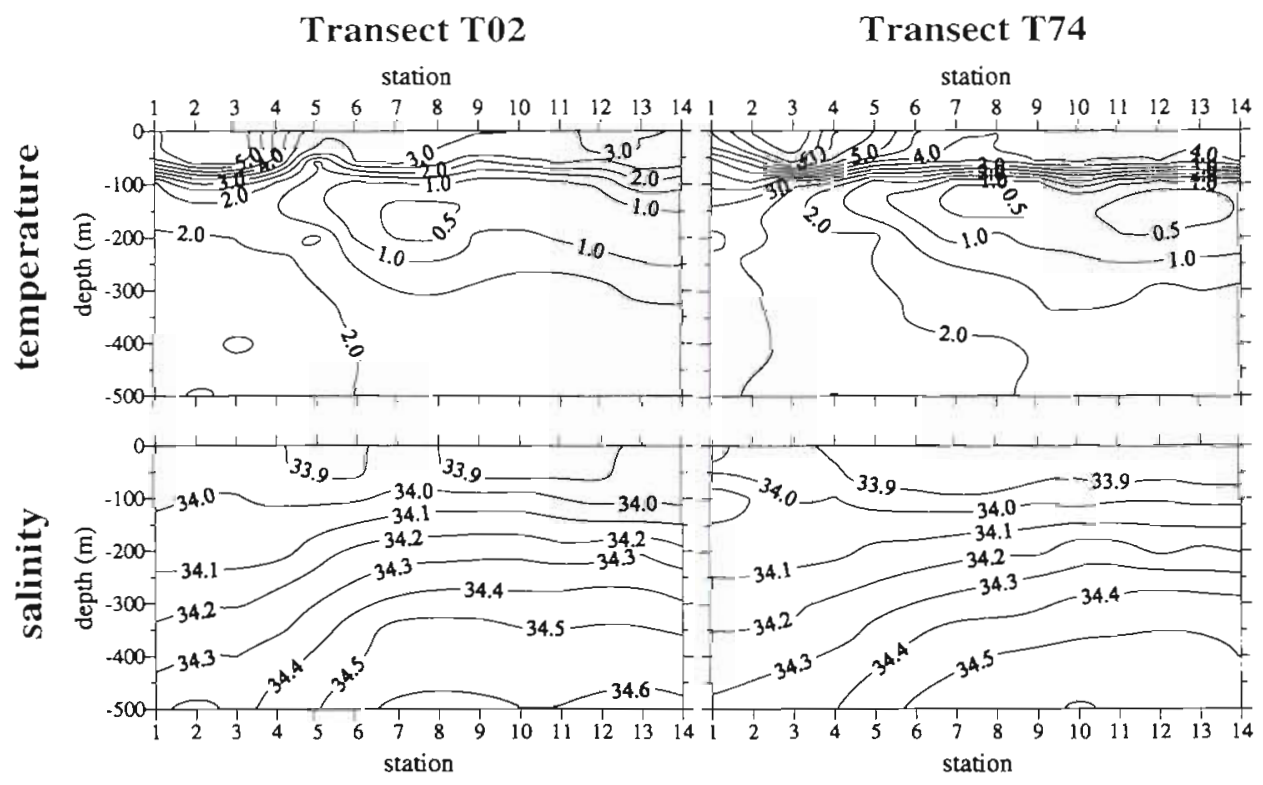




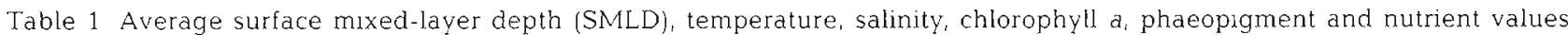
measured at the 14 stations along transects T02 and T74

\begin{tabular}{|c|c|c|c|c|c|c|c|c|c|c|c|}
\hline Stn & Transect & $\begin{array}{l}\text { SMLD } \\
\text { (m) }\end{array}$ & $\begin{array}{l}\text { Temp. } \\
\left({ }^{\circ} \mathrm{C}\right)\end{array}$ & Salinity & $\begin{array}{c}\text { Chl. a } \\
\left(\mathrm{mg} \mathrm{m}^{-3}\right)\end{array}$ & $\begin{array}{l}\text { Phaeo. } \\
\left(\mathrm{mg} \mathrm{m}^{-3}\right)\end{array}$ & $\begin{array}{c}\mathrm{NO}_{3}-\mathrm{N} \\
\left(\mathrm{mmol} \mathrm{m}^{-3}\right)\end{array}$ & $\begin{array}{c}\mathrm{NO}_{2}-\mathrm{N} \\
\left(\mathrm{mmol} \mathrm{m}^{-3}\right)\end{array}$ & $\begin{array}{c}\mathrm{NH}_{4}-\mathrm{N} \\
\left(\mathrm{mmol} \mathrm{m}^{-3}\right)\end{array}$ & $\begin{array}{l}\mathrm{Si}(\mathrm{OH})_{4}-\mathrm{Si} \\
\left(\mathrm{mmol} \mathrm{m}^{-3}\right)\end{array}$ & $\begin{array}{c}\mathrm{PO}_{4} \cdot \mathrm{P} \\
\left(\mathrm{mmol} \mathrm{m} \mathrm{m}^{-3}\right)\end{array}$ \\
\hline \multirow[t]{2}{*}{1} & TO2 & 35 & 5.38 & 33.93 & 0.9 & 0.45 & 20.07 & 0.22 & 0.37 & 9.50 & - \\
\hline & $\mathrm{T} 74$ & 40 & 5.70 & 33.88 & 2.9 & 0.77 & 11.23 & 0.26 & 0.31 & 3.57 & 1.30 \\
\hline \multirow[t]{2}{*}{2} & T02 & 60 & 5.88 & 33.97 & 1.1 & 0.13 & 19.66 & 0.21 & 0.36 & 7.47 & - \\
\hline & $\mathrm{T} 74$ & 50 & 6.31 & 33.96 & 2.0 & 0.53 & 10.75 & 0.24 & 0.55 & 2.51 & 1.32 \\
\hline \multirow[t]{2}{*}{3} & T02 & 50 & 5.95 & 33.97 & - & - & 20.77 & 0.19 & 0.21 & 6.92 & - \\
\hline & $T 74$ & 55 & 7.16 & 33.93 & 1.3 & 0.31 & 12.52 & 0.21 & 0.31 & 4.02 & 1.30 \\
\hline \multirow[t]{2}{*}{4} & T02 & 50 & 4.40 & 33.93 & 0.9 & 0.13 & 23.22 & 0.25 & 0.36 & 12.62 & - \\
\hline & $\mathrm{T} 74$ & 50 & 5.76 & 33.90 & 1.7 & 034 & 12.32 & 0.26 & 0.34 & 2.64 & 1.32 \\
\hline \multirow[t]{2}{*}{5} & $\mathrm{~T} 02$ & 30 & 2.98 & 33.82 & 2.0 & 0.07 & 22.48 & 0.28 & 0.22 & 3.09 & - \\
\hline & $\mathrm{T} 74$ & 50 & 5.03 & 33.82 & 1.4 & 0.36 & 21.67 & 0.26 & 0.32 & 8.15 & 1.38 \\
\hline \multirow[t]{2}{*}{6} & $\mathrm{~T} 02$ & 50 & 3.10 & 33.89 & 8.7 & 0.24 & 19.10 & 0.30 & 0.46 & 1.27 & - \\
\hline & T74 & 60 & 4.29 & 33.84 & 0.8 & 0.19 & 20.39 & 0.29 & 0.58 & 3.57 & 1.34 \\
\hline \multirow[t]{2}{*}{7} & TO2 & 60 & 3.19 & 33.96 & 1.9 & 0.18 & 24.10 & 0.27 & 0.44 & 14.69 & - \\
\hline & $\mathrm{T} 74$ & 60 & 3.90 & 33.79 & 17 & 0.35 & 20.90 & 0.29 & 0.19 & 10.98 & 1.32 \\
\hline \multirow[t]{2}{*}{8} & T02 & 60 & 3.01 & 33.90 & 3.4 & 0.34 & 21.07 & 0.29 & 0.54 & 7.45 & - \\
\hline & $\mathrm{T} 74$ & 50 & 3.92 & 33.80 & 1.8 & 0.29 & 18.74 & 0.30 & 0.56 & 6.98 & 1.11 \\
\hline \multirow[t]{2}{*}{9} & T02 & 55 & 2.93 & 33.87 & 7.5 & 0.60 & - & 0.30 & 0.42 & 3.83 & - \\
\hline & $\mathrm{T} 74$ & 65 & 4.20 & 33.87 & 2.4 & 0.63 & 16.83 & 0.29 & 1.02 & 5.91 & 1.04 \\
\hline \multirow[t]{2}{*}{10} & T02 & 50 & 2.93 & 33.87 & 13.5 & 0.29 & 10.08 & 0.30 & 0.44 & 5.81 & - \\
\hline & T74 & 60 & 4.28 & 33.89 & 2.4 & 0.45 & 17.19 & 0.28 & 0.80 & 5.10 & 1.12 \\
\hline \multirow[t]{2}{*}{11} & T02 & 55 & 2.72 & 33.89 & 11.7 & 0.21 & 11.39 & 0.30 & 0.37 & 10.12 & - \\
\hline & $\mathrm{T} 74$ & 65 & 4.15 & 33.86 & 2.8 & 0.68 & 15.14 & 0.31 & 0.92 & 3.55 & 1.04 \\
\hline \multirow[t]{2}{*}{12} & T02 & 50 & 3.23 & 33.88 & 4.7 & 0.08 & 12.32 & 0.30 & 0.69 & 3.15 & - \\
\hline & $\mathrm{T} 74$ & 70 & 4.13 & 33.88 & 2.8 & 0.93 & 13.81 & 0.29 & 1.07 & 4.64 & 1.00 \\
\hline \multirow[t]{2}{*}{13} & T02 & 70 & 2.97 & 33.93 & 3.7 & 0.49 & 15.54 & 0.28 & 0.70 & 13.54 & - \\
\hline & $\mathrm{T} 74$ & 40 & 3.97 & 33.86 & - & - & 14.44 & 0.29 & 1.41 & 5.37 & 1.14 \\
\hline \multirow[t]{2}{*}{14} & T02 & 60 & 2.82 & 33.91 & - & - & 13.48 & 0.28 & 0.72 & 12.14 & - \\
\hline & T74 & 50 & 4.25 & 3385 & 7.6 & 1.64 & 12.83 & 0.31 & - & 4.94 & 1.01 \\
\hline
\end{tabular}

sect T02 at Stns 1 to 4 average SML chlorophyll concentrations of $\sim 1.0 \mathrm{mg} \mathrm{m}^{-3}$ or less were measured, whereas all other stations to the south had SML values of $\sim 2.0 \mathrm{mg} \mathrm{m}^{-3}$ or more (Table 1). However, there were 2 patches of particularly high levels of chlorophyll at Stn 6 and between. Stns 9 and 11 (average SML concentration 8.7 and $13.5 \mathrm{mg} \mathrm{m}^{-3}$ respectively). Phaeopigment concentrations were generally low along the transect [average SML concentration $0.27 \mathrm{mg} \mathrm{m}^{-3}$, or $\sim 8 \%$ of total plant pigments (TPP)] Chlorophyll distribution was far more uniform along transect T74, with concentrations between 1.0 and $3.0 \mathrm{mg} \mathrm{m}^{-3}$ at most stations. One notable exception to this was at the southernmost station where the average chlorophyll concentration was $7.6 \mathrm{mg} \mathrm{m}^{-3}$ in the SML. Phaeopigment levels were significantly higher than in the earlier transect $(F=18.572, \mathrm{p}<0.001)$, with an average SML concentration of $0.57 \mathrm{mg} \mathrm{m}^{-3}$, or $\sim 19 \%$ of TPP.

\section{Nutrients}

There was considerable variability in nitrate distribution along both transects. During transect T02 a substantial SML depletion (down to $10.08 \mathrm{mmol} \mathrm{m}^{-3}$ ) appeared to coincide with elevated chlorophyll levels around Stn 10 (Fig. 4, Table 1). Further depletion was evident at Stn 14 and to a lesser extent Stn 6 (13.48 and $19.10 \mathrm{mmol} \mathrm{m}^{-3}$ respectively). Indeed there was a strong negative correlation between chlorophyll and mitrate $(r=-0.791, n=11)$. No such correlation was evident along transect T74, although the lowest concentration south of the PF $\left(12.83 \mathrm{mmol} \mathrm{m}^{-3}\right)$ was at Stn 14 where chlorophyll levels were highest. Along transect T74 concentrations gradually increased northwards up to $\mathrm{Stn}$ 5, after which lower levels between 10.75 and $12.52 \mathrm{mmol} \mathrm{m}^{-3}$ were measured at Stns 1 to 5 in the $\mathrm{SAZ}$ and the PFZ.

Nitrite concentrations greater than $0.1 \mathrm{mmol} \mathrm{m}^{-3}$ were generally confined to the top $100 \mathrm{~m}$ of the water column and there was a positive correlation between nitrite and chlorophyll concentrations along transect T02 ( $r=0.702, n=12)$. Concentrations were $\sim 0.25 \mathrm{mmol}$ $m$ in the SML, but were up to $0.3 \mathrm{mmol} \mathrm{m}^{-3}$ at Stns 9 to 12 in the presence of elevated chlorophyll levels (Table 1). Along transect T74 the highest SML nitrite concentration also coincided with the highest chlorophyll level, but along much of the transect the highest levels (up to $0.40 \mathrm{mmol} \mathrm{m}^{-3}$ ) were found at the bottom of, or slightly below, the SML (Fig. 4) 

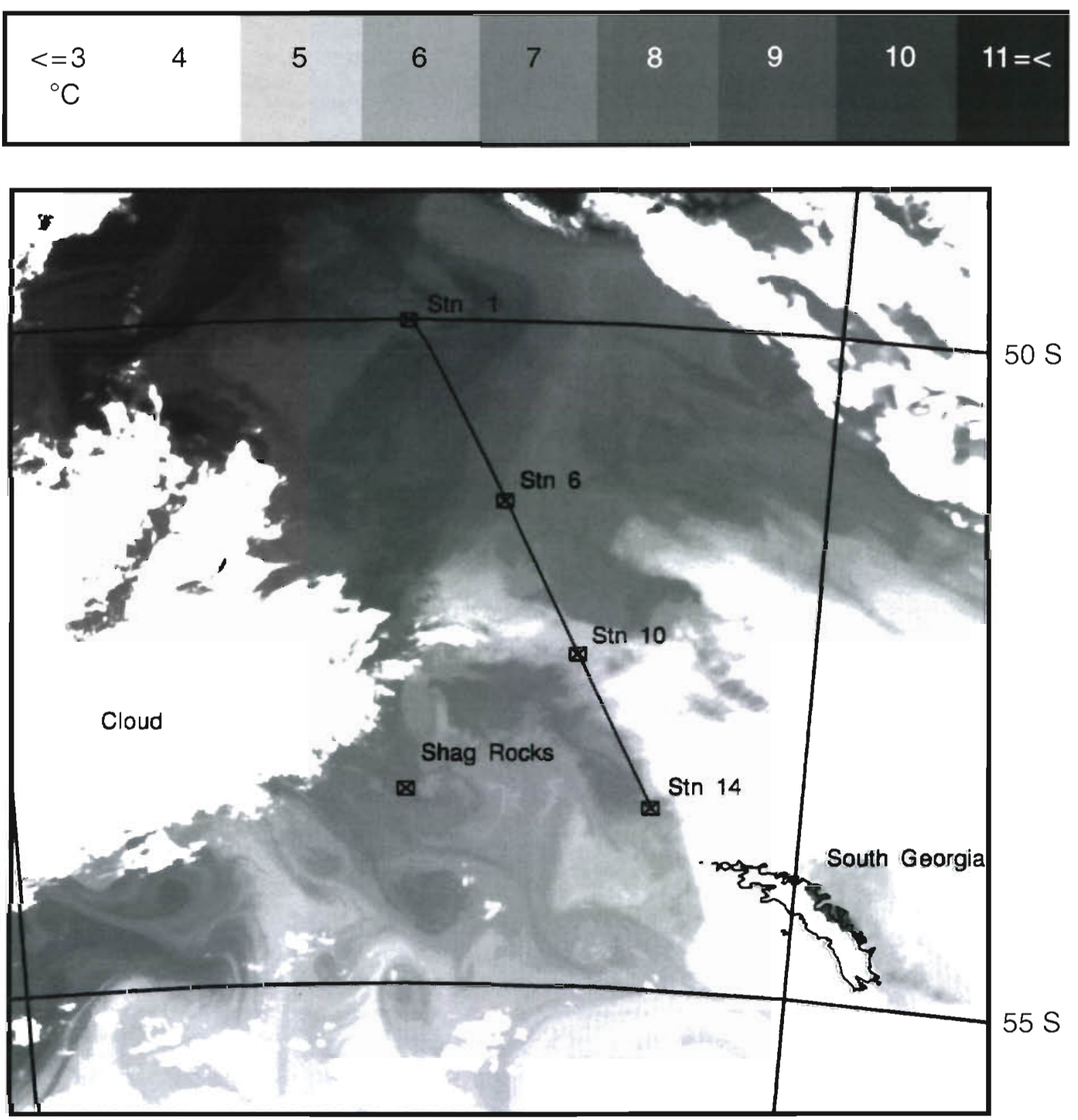

$47 \mathrm{~W}$

$37 \mathrm{~W}$

Fig. 3. AVHRR satellite image taken at $20: 30 \mathrm{~h} \mathrm{GMT,} 3$ February 1994 . Note the warmer water (plus $\sim 4^{\circ} \mathrm{C}$ ) protrusion to the southwest of Shag Rocks, and the surface signatures of eddy-like structures $\left(<100 \mathrm{~km}\right.$ in horizontal extent and $-1^{\circ} \mathrm{C}$ warmer than the surrounding water) to the south of Shag Rocks

Ammonium concentrations along both transects were high for Antarctic open-ocean water. Concentrations greater than $0.15 \mathrm{mmol} \mathrm{m}^{-3}$ were mainly confined to the top $100 \mathrm{~m}$ or so of the water column and the highest SML levels were at the most southerly stations along both transects (Table 1). However, the most obvious ammonium feature was the elevated concentrations at or below the bottom of the SML, which formed a continuous layer south of Stn 5 along transect T02 and was almost as extensive along transect T74 (Fig. 4). Maximum concentrations in this sub-surface layer were also at the southern end of the transects: T02: Stn 14, $102 \mathrm{~m}_{2} .01 \mathrm{mmol} \mathrm{m}^{-3}$; and T74: Stn 12, $101 \mathrm{~m}, 2.11 \mathrm{mmol} \mathrm{m}^{-3}$

There was considerable variation in SML silicate distribution along both transects, but concentrations 


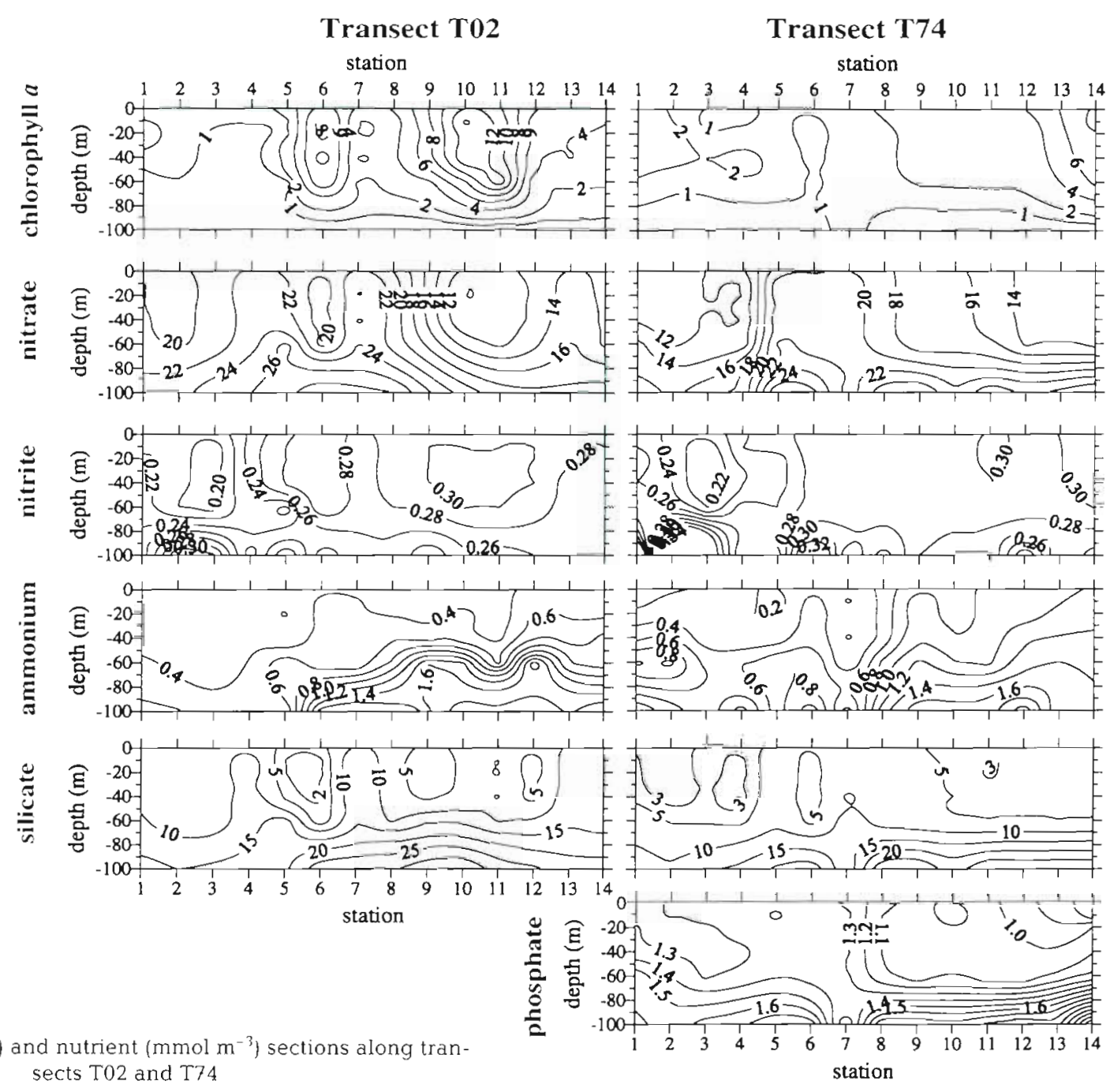

Fig. 4. Chl a $\left(\mathrm{mg} \mathrm{m}^{-3}\right)$ and nutrient $\left(\mathrm{mmol} \mathrm{m}^{-3}\right)$ sections along transects $\mathrm{T} 02$ and $T 74$

Antarctic Ocean. Turbulent mixing in the permanently open (ice-free) ocean is a major factor governing phytoplankton growth, and open-ocean chlorophyll levels in the Scotia Sea and to the north of South Georgia are generally $<2.5 \mathrm{mg} \mathrm{m}^{-3}$ (Glibert et al. 1982, Rönner et al. 1983, Priddle et al. 1986. Whitehouse et al. 1993, in press). Therefore it is most unlikely that either of the phytoplankton blooms on transect T02 was a purely open-ocean event. The northernmost bloom appeared to be associated with the PF jet, whereas the southern bloom may have been associated with a mesoscale feature of some sort. The maximum chlorophyll concentration of $\sim 8 \mathrm{mg} \mathrm{m}^{-3}$ measured at Stn 6 on transect $\mathrm{T} 02$ is high for a frontal bloom, however levels measured at Stn 10 of greater than $12 \mathrm{mg} \mathrm{m}^{-3}$ are exceptional in open Antarctic waters.

Enhanced production or accumulated biomass, due to shelf-break and island-mass effects, have previously been observed near to South Georgia and other subantarctic islands (e.g Priddle et al. 1986, Perissinotto et northwest of South Georgia during January and February 1994 have rarely been reported from the open 
al. 1992, Whitehouse et al. 1993, in press). However, these mechanisms are unlikely to be responsible for generating the phytoplankton blooms in the present study as they occurred in the deep ocean (>3000 m), $150 \mathrm{~km}$ or more to the northwest of South Georgia. During the 'Islas Orcadas' cruise 17 in 1978, El-Sayed \& Weber (1982) recorded chlorophyll concentrations of between 11 and $13 \mathrm{mg} \mathrm{m}^{-3}$ at their deep ocean Stn 34 $-65 \mathrm{~km}$ northeast of $\operatorname{Stn} 9$ in the present study. However, they were unsure what factors contributed to the enhanced phytoplankton biomass. Fryxell et al. (1979) also described phytoplankton observations made along a transect of 4 stations from the same 'Islas Orcadas' cruise, including Stn 34. They speculated that the phytoplankton at this station represented a gradually aging population, perhaps seeded from South Georgia and carried in a large semi-circular path or possibly entrapped in some sort of gyre. Here we consider the generation of the transect T02 blooms and the absence of such blooms 1 mo later during transect $\mathrm{T} 74$

\section{The Polar Front bloom}

Increased phytoplankton biomass at fronts may be due to physical accumulation of particulate matter in areas of convergence (e.g. Franks 1992), or to enhanced productivity due to more favourable conditions associated with the front (Allanson et al. 1981, Laubscher et al. 1986, 1993). We are unable to determine which mechanism was responsible for the PF bloom as production rates were not measured during the present study. However, the low phaeopigment concentrations $\left(0.24 \mathrm{mg} \mathrm{m}^{-3},<3 \%\right.$ of the TPP), and the coincidence of high chl a concentrations with distinctly depleted nutrient levels, suggest active growth.

Laubscher et al. (1993) reported a close association between chlorophyll and silicate concentrations in the vicinity of the PF, and that the main controlling factor of phytoplankton growth appeared to be the spatial covariance between silicate levels and water column stability. They commented that of all the macronutrients only silicate may be present at limiting concentrations north of the PF, and that productivity may be favoured at the southern edge of the PF where higher concentrations are available. De Baar et al. (1995) measured chlorophyll and iron concentrations along a transect which crossed the PF at $\sim 6^{\circ} \mathrm{W}$, some $2500 \mathrm{~km}$ to the east of the JR06 transects. They reported a sharp delineation between plankton- and iron-rich PF waters and adjacent plankton- and ironpoor ACC waters. They proposed that sediments from the Northeastern Georgia Ridge (which the ACC passes over $1900 \mathrm{~km}$ west of their transect) may have been the iron source, and found that iron concentrations decreased eastwards as biogenic particles settled out of the surface waters.

Several factors are pertinent to the bloom's generation and subsequent demise. The geostrophic flows and T/S measurements reported by Trathan et al. (unpubl.) indicated that 3 water regimes met in the vicinity of the bloom around Stn 6 during transect T02, which presents the site with several possible import mechanisms. Firstly, the area could be seeded from South Georgia as speculated by Fryxell et al. (1979). Secondly, the North Scotia Ridge $\sim 400 \mathrm{~km}$ to the west of the position of the present study's Stn 6 could be a potential iron source to the PF jet in the ACC. Thirdly, there may have been a link between the PF and the larger southern bloom observed on transect $\mathrm{TO} 2$

Although nitrate concentrations were noticeably lower at Stn 6 during transect T02, overall nitrate and phosphate levels were high. However, silicate concentrations were particularly low at the PF during transect T02 and may have been a controlling factor for diatom dominated phytoplankton growth

\section{The southern bloom}

Along transect T02, elevated chlorophyll concentrations were generally coincident with depleted nitrate and silicate levels. During transect T74, chlorophyll distribution was more uniform and, apart from the most southerly station, concentrations were lower and more typical of the open ocean (cf. Tréguer \& Jacques 1992). Yet, although the nutrient distribution was also more uniform, concentrations remained similar to the earlier transect. Here, we speculate on the dynamics of the bloom observed on transect T02 and on its possible fate. Since we only have 2 observations of the area, separated by 1 mo, we have no concrete evidence for the time course of phytoplankton dynamics in the region. In particular, we cannot assume continuity of water type between the corresponding portions of the 2 transects. However, we can perform simple budget calculations based on different possible water mass origins, and their associated nutrient signatures, and use these calculations to assess a range of phytoplankton bloom sizes and fates.

Although we have information on chlorophyll standing stocks for the 2 transects and the corresponding nutrient fields, we lack definitive data on the starting concentrations (i.e. winter values) for the nutrients. Therefore, we will concentrate on 2 plausible scenarios, and their implications for phytoplankton dynamics in the 2 transect surveys. The first possibility, and the one which requires the least assumptions about the physical system, is that the southern bloom developed 
in Antarctic Zone (AAZ) water. This would suggest significant loss of phytoplankton not only between the first and second observations of the transect, but also prior to the first observation (transect T02) because AAZ winter nutrient concentrations are higher than those observed. The second possibility we examine here is the advection across the Polar Front of water with lower nutrient loading. To model this, we have taken winter concentrations calculated by using a nutrient budget calculated from transect T02 observations, and applied this to transect T74.

\section{A bloom in AAZ surface water}

We have calculated nutrient and chlorophyll budgets for the upper $50 \mathrm{~m}$ of the water column. Starting conditions have been assumed to be typical winter AAZ concentrations for the vicinity of South Georgia. We have taken 2 approaches, which yield very similar results (Table 2). In the first, we have used the $100 \mathrm{~m}$ concentrations from the current study's stations as indications of winter mixed-layer concentrations. Water at this depth is within the mixed layer in winter, but beneath the summer pycnocline as is indicated by the presence of a temperature minimum ( $\mathrm{T}_{\text {min }}$; see Fig. 2). As a second, and independent, predictor of winter AAZ concentrations, we have taken averaged winter values from 11 stations sampled during winter in the same region as the present transect (see Whitehouse et al. 1993, in press).

In this scenario we have assumed a common origin for the water at Stns 9 to 12 in the 2 transect surveys, and have calculated nutrient and chlorophyll budgets based on average AAZ properties. This does not suggest that there was physical continuity between the two, but simply that they shared the same starting conditions.

The silicate deficits were consistent for both calculation methods. For transect T02 the silicate deficit implied an average chlorophyll production of $1092 \mathrm{mg}$ $\mathrm{m}^{-2}$ which is much higher than the observed biomass of $415 \mathrm{mg} \mathrm{m}^{-2}$ in the bloom. Similarly for transect T74, the silicate deficit implied a chlorophyll production of $1105 \mathrm{mg} \mathrm{m}^{-2}$ as opposed to the observed value of $130 \mathrm{mg} \mathrm{m}^{-2}$

The nitrate and phosphate calculations were more variable. Nitrate deficits were considerably lower than those of silicate and phosphate implying that nitrate was not the sole source of nitrogen ( $f$-ratio 1.0) for phytoplankton growth. For transect T02 an $f$-ratio of $0.69(0.59$ to 0.78$)$ and for transect $T 74$ a lower $f$-ratio of $0.55(0.46$ to 0.63$)$ would produce a similar deficit to that of silicate. Because of the uncertainty of the contribution of alternative nitrogen sources to phytoplankton growth and the unknown degree of remineralisation of both nitrate and phosphate, silicate-implied production was considered the most reliable.

The growth of a phytoplankton population giving rise to a bloom can be modelled by:

$$
B_{t}=B_{0} \exp (\mu t)
$$

where $B_{t}$ and $B_{0}$ are the biomass at time $t$ and at the start of the bloom respectively (the latter calculated from the average chlorophyll value measured in this

Table 2. Average depth-integrated chlorophyll a ( $\mathrm{chl}$ a) biomass, increase in chl a biomass from winter levels, plus nutrient deficits and their implied increase in chl a biomass for the upper $50 \mathrm{~m}$ of the water column for Stns 9 to 12 inclusive, transects To2 and T74. Nutrient deficits were calculated with reference to (A) $100 \mathrm{~m}$ concentrations measured during the same study, and (B) averaged $50 \mathrm{~m}$ integrated values for 11 stations surveyed in the same region northwest of South Georgia during winter

\begin{tabular}{|c|c|c|c|c|}
\hline Transect & T02 & T02 & T74 & T74 \\
\hline Observed chl a biomass (mg m$\left.{ }^{-2}\right)$ & 415 & - & 130 & - \\
\hline${ }^{\circ}$ Increase in chl a biomass from winter levels $\left(\mathrm{mg} \mathrm{m}^{-2}\right)$ & 404 & - & 119 & - \\
\hline Nutrient deficit calculation reference & A & B & A & $\mathrm{B}$ \\
\hline $\mathrm{Si}(\mathrm{OH})_{4}$ deficit $\left(\mathrm{mmol} \mathrm{m}^{-2}\right)$ & 1189 & 1086 & 1156 & 1147 \\
\hline${ }^{b}$ Implied increase in chl a biomass ( $\mathrm{mg} \mathrm{m}^{-2}$ ) & 1141 & 1042 & 1109 & 1100 \\
\hline $\begin{array}{l}\mathrm{NO}_{3} \text { deficit }\left(\mathrm{mmol} \mathrm{m} \mathrm{m}^{-2}\right) \\
\text { Implied increase in chl a biomass }\left(\mathrm{mg} \mathrm{m}^{-2}\right)\end{array}$ & $\begin{array}{l}405 \\
643\end{array}$ & $\begin{array}{l}537 \\
853\end{array}$ & $\begin{array}{l}435 \\
691\end{array}$ & $\begin{array}{l}320 \\
508\end{array}$ \\
\hline $\begin{array}{l}{ }^{\mathrm{C}} \mathrm{PO}_{4} \text { deficit (mmol m}{ }^{-2} \text { ) } \\
\text { 'Implied increase in chl a biomass }\left(\mathrm{mg} \mathrm{m}^{-2}\right)\end{array}$ & $\begin{array}{l}- \\
-\end{array}$ & - & $\begin{array}{r}38 \\
966\end{array}$ & $\begin{array}{r}52 \\
1322\end{array}$ \\
\hline \multicolumn{5}{|c|}{$\begin{array}{l}\text { "An average } 0 \text { to } 50 \mathrm{~m} \text { winter value of } 0.22 \mathrm{mg} \mathrm{m}^{-3} \text { measured during August } 1983 \text { equates to an upper } 50 \mathrm{~m} \text { integrated value } \\
\text { of } 11 \mathrm{mg} \mathrm{m}^{-2} \text { (Whitehouse et al. in press) } \\
\text { "Nutrient:biomass relationships were calculated using the following phytoplankton carbon (mmol) equivalents; } 4.17 \times \text { chloro- } \\
\text { phyll. (mg); } 4 \times \text { silicate (mmol) (Priddle et al. } 1995 \text { ); } 6.625 \times \text { nitrate (mmol) (Redfield C: } N \text {, uptake } f \text { ratio }=1 \text { ); } 106 \times \text { phosphate } \\
\text { (mmol) (Redfield C:P) } \\
\text { "Phosphate was not determined during transect T02 }\end{array}$} \\
\hline
\end{tabular}


area during winter $1983 ; 0.22 \mathrm{mg} \mathrm{m}^{-2}$ in the top $50 \mathrm{~m}$ of the water column; see Whitehouse et al. 1993, in press), and $\mu$ is the natural log of the growth rate. If the observed biomass, $B_{i}{ }^{*}$, had resulted from the net balance between growth and loss, then:

$$
B_{t}^{*}=B_{0} \exp [\mu(1-L) t]
$$

where $L$ is a loss parameter scaled to $\mu$. Note that the budget calculations in the subsequent discussion are independent of growth rate, for which we have no data concurrent with the transect studies. $L$ can be calculated by:

$$
L=1-\left(\frac{\ln B_{i}^{*}-\ln B_{0}}{\ln B_{t}-\ln B_{i)}}\right)
$$

For transect $\mathrm{T} 02, L_{\mathrm{T} 02}=0.225$, or a realised loss rate of $0.225 \mu$.

As noted above, for transect T74 the silicate deficit implies a chlorophyll production of $1105 \mathrm{mg} \mathrm{m}^{-2}$, similar to that calculated for transect T02 but much higher than the observed value of $130 \mathrm{mg} \mathrm{m}^{-2}$, and for which a loss parameter value of $L_{T 74}=0.465$ can be calculated. Therefore if the similar nutrient fields measured along the 2 transects had resulted from similar-sized phytoplankton blooms, the losses from each bloom were considerably different. The phytoplankton biomass predicted by nutrient drawdown in transect T02 implies considerable loss when compared with observation. If we assume that this loss rate represented in situ processes such as grazing, then the additional losses which would be needed to produce the lower chlorophyll biomass observed in transect T74 can be calculated. Using the modified population growth equation, we can express the observed biomass on transect $T 74, B_{t}^{\prime \prime}$, as:

$$
B_{t}^{\prime \prime}=B_{0} \exp \left[\mu\left(1-L_{\mathrm{T} 74}\right) t^{\prime \prime}\right]
$$

where $L_{T 74}$ is the average value of the loss parameter applied over the time of the evolution of the bloom $t^{\prime \prime}$. However, we can also write a similar equation for a theoretical biomass, $B_{b}$, which would have arisen if the loss parameter from transect T02, $L_{\text {T02 }}$, had applied:

$$
B_{b}=B_{0} \exp \left[\mu\left(1-L_{\mathrm{T} 02}\right) t^{\prime \prime}\right]
$$

By combining these 2 equations, we can calculate a value for $B_{b}$ without knowing either $\mu$ or $t^{\prime \prime}$ :

$$
B_{b}=\ln B_{0} \times \exp \left[\left(\ln B_{t}{ }^{\prime \prime}-\ln B_{0}\right) \times\left(\frac{1-L_{\top 02}}{1-L_{\mathrm{T} 74}}\right)\right]
$$

For transect T74, $B_{b}=385 \mathrm{mg} \mathrm{m}^{-2}$ and the additional overall loss of biomass can then be calculated by subtracting this from the biomass predicted on the basis of nutrient drawdown, which was $1040 \mathrm{mg} \mathrm{m}^{-2}$. The calculated removal of $685 \mathrm{mg} \mathrm{m}^{-2}$ equates to a removal of $\sim 2.7 \mathrm{~mol} \mathrm{C} \mathrm{m}{ }^{-2}$ from the top $50 \mathrm{~m}$ of the water column over the lifetime of the bloom, a similar figure to the total seasonal primary production predicted by Whitehouse et al. (in press) for the South Georgia area as a whole.

Two possible explanations of such losses between the 2 transects would be mass sedimentation or extremely high grazing rates. We have no observations for or against mass sedimentation but net samples taken at all CTD stations and continual acoustic searches show a particular lack of zooplankton grazers along both transects in a year of particularly low krill densities in the entire South Georgia area (P. Ward \& J. L. Watkins, BAS, pers. comm.).

\section{A bloom in lower-nutrient water}

The satellite image clearly shows the surface signatures of warm water protruding eastward from the PF, and eddy-like features, of a similar horizontal scale to the southern bloom, to the west of South Georgia (Fig. 3). As surface water from north of the PF is likely to have lower nutrient concentrations than AAZ water (Tréguer et al. 1987), it is possible that relatively lownutrient water had been advected into the study area. The lowest possible starting concentrations for the southern bloom an transect $\mathrm{T} 02$ would be the observed values plus the amount of nutrient drawdown implied by the observed chlorophyll biomass. This means that there would have been no further removal of nutrients by loss of phytoplankton biomass. On this basis, the integrated winter silicate concentration for transect T02 would have been $705 \mathrm{mmol} \mathrm{m}^{-2}$ and nitrate would have been $814 \mathrm{mmol} \mathrm{m}^{-2}$. These values correspond to average concentrations in the upper $50 \mathrm{~m}$ of 14 and $16 \mathrm{mmol} \mathrm{m} \mathrm{m}^{-3}$ respectively, and would be compatible with water originating in the adjacent PFZ.

In this scenario, we can repeat our budget calculation for transect T74, but using the lower predicted winter concentrations for PFZ water based on the calculations for transect T02. Again, we are not implying a physical connection between the regions in the 2 transects - merely a common origin. Recalling that we calculated the PFZ nutrient concentrations on the basis that there had been no loss of phytoplankton biomass from the transect T02 bloom, the value of the loss parameter $L_{\mathrm{T} 02}=0$ (by definition). The difference in phytoplankton standing stock, and the nutrient fields, remains identical to the previous (AAZ) scenario, but the value of the loss parameter for transect T74 is reduced $-L_{\mathrm{T} 74}=0.351$. Although higher than the value of this parameter which we attributed to grazing for transect T02 in the AAZ scenario, it is lower than that for transect T74 AAZ simulation and implies significantly less carbon export. 


\section{CONCLUSION}

We have described nutrient and chlorophyll fields for 2 surveys of the same oceanographic transect, separated by $1 \mathrm{mo}$. In the case of the first run, transect T02, there was a phytoplankton bloom associated with the Polar Front and an even stronger and more extensive bloom further to the south. Associated with each were deficits in the surface water nutrient fields which appeared to be linked to drawdown arising from phytoplankton growth. On the second run along the transect (T74), nutrient fields were similar to those encountered 1 mo earlier, but chlorophyll biomass was lower. In discussing these data, we have examined the implications for the fate of phytoplankton carbon. We have concentrated on the southern bloom because it was a larger and more coherent feature and one for which we could supply more background data.

in carrying out simulations of the dynamics of the southern bloom, we have put forward 2 interpretations for the observations of nutrient and chlorophyll fields. At one extreme, and the one which requires the least assumptions about the physical system, we have the possibility that the southern bloom observed on transect T02 occurred within the AAZ, and that continuity with the same region on transect T 74 implies a significant removal of phytoplankton carbon which cannot be explained by the likely grazing pressure. Alternatively, eddy-shedding by the ACC is a common feature where it crosses prominent bottom topography (Gordon et al. 1977, Lutjeharms \& Baker 1980, Bryden 1983, Nowlin \& Klinck 1986), and the advection of lower-nutrient water into the study area might imply lower or negligible carbon export.

Possible physical mechanisms exist for all scenarios, but the data available to us from the 2 hydrographic sections and from scarce contemporary satellite imagery do not allow us to identify the mechanisms responsible for generating and maintaining the blooms. However, it seems that our observations of high biomass and evidence for active growth (rather than simply of biomass accumulation) imply that such blooms may be important features of the region between South Georgia and the PF. Furthermore, they may be significant, albeit local, regions of carbon export.

Acknowledgements. We thank scientists, officers and crew aboard the RRS 'James Clark Ross' dunng cruise JR06 for their assistance with data collection. Pete Ward and Jon Watkins for providing zooplankton data, Tom Lachlan-Cope, Russell Ladkin and Richard Siddans for help with preparing the AVHRR image, and Francis Daunt for his assistance with the compilation of Fig. 1. We are also grateful to Eugene Murphy and 4 anonymous referees for their constructive comments on the manuscript.

\section{LITERATURE CITED}

Allanson BR, Hart RC, Lutjeharms JRE (1981) Observations on the nutrients, chlorophyli and primary production of the Southern Ocean south of Africa. S Afr J Ant Res 10/11. $3-13$

Boden BP (1988) Observations of the Island Mass Effect in the Prince Edward Archipelago. Polar Biol 9: 61-68

Boyd PW, Robinson C, Savidge G. Willams PJ leB (1995) Water column and sea-1ce primary production during austral spring in the Bellingshausen Sea. Deep Sea Res II 33. $1177-1200$

Bryden HL (1983) The Southern Ocean. In: Robinson AR (ed) Eddies in marine science. Springer-Verlag, Berlin, p 265-277

Bury SJ, Owens NJP, Preston T $(1995){ }^{13} \mathrm{C}$ and ${ }^{15} \mathrm{~N}$ uptake by phytoplankton in the marginal ice zone of the Bellıngshausen Sea. Deep Sea Res II 33:1225-1252

Cota GT, Smith WO Jr, Nelson DM, Muench RO, Gordon LI (1992) Nutrient and biogenic particulate distributions, primary productivity and nitrogen uptake in the WeddellScotia Sea marginal ice zone during winter. J Mar Res 50 155-181

De Baar HJW, De Jong JTM, Bakker DCE, Löscher BM, Veth C, Bathmann U, Smetacek V (1995) Importance of iron for plankton blooms and carbon dioxide drawdown in the Southern Ocean. Nature 373:412-415

El-Sayed SZ, Weber LH (1982) Spatial and temporal variations in phytoplankton biomass and primary production in the southwest Atlantic and Scotia Seas. Polar Biol 1:83-90

Franks PJS (1992) Sink or swim: accumulation of biomass at fronts. Mar Ecol Prog Ser 82:1-12

Fryxell GA, Villareal TA, Hoban MA (1979) Thalassiosira scotia, sp. nov.: observations on a phytoplankton increase in early austral spring north of the Scotia Ridge. J Plankton Res 1:355-370

Glibert PM, Biggs DC, McCarthy JJ (1982) Uttlization of ammonium and nitrate during the austral summer in the Scotia Sea. Deep Sea Res 29:837-850

Gordon AL, Georgi DT, Taylor HW (1977) Antarctic polar front zone in the western Scotia Sea, summer 1975. J Phys Oceanogr 7:309-328

Hardy AC (1967) Great waters. Collins, London

Hardy AC. Gunther ER (1935) The plankton of the South Georgia whaling grounds and adjacent waters, $1926-$ 1927. Discovery Rep 11:1-456

Heywood RB, Priddle J (1987) Retention of phytoplankton by an eddy. Cont Shelf Res 7:937-955

Holm-Hansen O, Mitchell BG (1991) Spatial and temporal distribution of phytoplankton and primary production in the western Bransfield Stralt region. Deep Sea Res 38: $961-980$

Jacques G (1989) Primary production in the open Antarctic Ocean during the austral summer A review. Vie Milieu 39:1-17

Jacques $G$, Panouse M (1991) Biomass and composition of size fractionated phytoplankton in the Weddell-Scotia Confluence area. Polar Biol 11:315-328

Laubscher JRE, Allanson BR, Parker L (1986) Frontal zones, chlorophyll and primary production patterns in the surface waters of the Southern Ocean south of Cape Town. In Nihoul JCJ (ed) Marine interfaces ecohydrodynamics. Elsevier Oceanography Series, Amsterdam, p 1.05-117

Laubscher RK, Perissinotto R, McQuaid CD (1993) Phytoplankton production and biomass at frontal zones in the Atlantic sector of the Southern Ocean. Polar Bıol 13: $471-481$ 
Lutjeharms JRE, Baker D Jr (1980) A statistical analysis of the meso-scale dynamics of the Southern Ocean. Deep Sea Res 27:145-159

Lutjeharms JRE, Walters NM, Allanson BR (1985) Oceanic frontal systems and biological enhancement. In: Siegfried WR, Condy PR, Laws RM (eds) Antarctic nutrient cycles and food webs. Springer-Verlag, Berlin, $p$ 11-21

Nelson DM, Smith WO Jr, Gordon LI, Huber BA (1987) Spring distributions of density, nutrients, and phytoplankton biomass in the ice edge zone of the Weddell-Scotia Sea. J Geophys Res 92:7181-7190

Nelson DM, Smith WO Jr, Muench RD, Gordon LI, Sullivan CW. Husby DM (1989) Particulate matter and nutrient distributions in the ice-edge zone of the Weddell Sea: relationship to hydrography during late summer. Deep Sea Res 36:191-209

Nowlin WD Jr, Klinck JM (1986) The physics of the Antarctic Circumpolar Current. Rev Geophys 24:469-491

Orsi AH, Whitworth T III, Nowlin WD Jr (1995) On the meridional extent and fronts of the Antarctic Circumpolar Current. Deep Sea Res 42:641-673

Parsons TR, Maita Y, Lalli CM (1984) A manual of chemical and biological methods for seawater analysis. Pergamon Press, Oxford

Perissinotto R, Laubscher RK, McQuaid CD (1992) Marine productivity enhancement around Bouvet and the South Sandwich Islands (Southern Ocean). Mar Ecol Prog Ser 88: 41-53

Peterson RG, Whitworth T III (1989) The Subantarctic and Polar Fronts in relation to deep water masses through the southwestern Atlantic. J Geophys Res 95:10817-10838

Priddle J, Heywood RB, Theriot E (1986) Some environmental factors influencing phytoplankton in the Southern Ocean around South Georgia. Polar Biol 5:65-79

Priddle J, Leaky R, Symon C, Whitehouse M, Robins D, Cripps G, Murphy E, Owens N (1995) Nutrient cycling by Antarctic marine microbial plankton. Mar Ecol Prog Ser 116:181-198

Rönner U, Sorensson F, Holm-Hansen O (1983) Nitrogen assimilation by phytoplankton in the Scotia Sea. Polar Biol $2: 137-147$

This article was submitted to the editor
Savidge G, Harbour D, Gilpin LC, Boyd PW (1995) Phytoplankton distribution and production in the Bellingshausen Sea, austral spring 1992. Deep Sea Res Il 33: $1201-1224$

Sievers HA, Nowlin WD Jr (1988) Upper ocean characteristics in Drake Passage and adjoining areas of the Southern Ocean, $39^{\circ} \mathrm{W}-95^{\circ} \mathrm{W}$. In: Sahrhage D (ed) Antarctic Ocean and resources variability. Springer-Verlag, Berlin, p 57-80

Smith WO, Nelson DM (1985) Phytoplankton bloom produced by a receding ice-edge in the Ross Sea: spatial coherence with the density field. Science 227:163-166

Tréguer P, Appriou P, Bordin G, Cuet P, Le Jehan S, Souchu P (1987) Caractéristiques physiques et chimiques des masses d'eaux du secteur indien de l'océan austra] au sud du Front Polaire (Mer d'Amery) (Campagne Apsara II Antiprod III, 1984). In: Fontugne M, Fiala M (eds) Caractéristiques biologiques, chimiques et sédimentologiques du secteur indien de l'océan austral (Plateau de Kerguélen). Rapport du Campagne de la Mer, TAAF 84-01. Terres Australes et Antarctiques Française, Paris, p $54-74$

Tréguer $P$, Jacques G (1992) Dynamics of nutrients and phytoplankton, and fluxes of carbon nitrogen and silicon in the Antarctic Ocean. Polar Biol 12:149-162

Whitehouse MJ, Priddle J, Symon C (in press) Seasonal and annual change in seawater temperature, salinity, nutrient and chlorophyll a distribution around South Georgia, South Atlantic. Deep Sea Res

Whitehouse MJ, Priddle J, Woodward EMS (1995) Spatial variability of inorganic nutrients in the marginal ice zone of the Bellingshausen Sea during the austral spring. Deep Sea Res II 33:1047-1058

Whitehouse MJ, Symon C, Priddle J (1993) Variations in the distribution of chlorophyll a and inorganic nutrients around South Georgia, South Atlantic. Antarct Sci 5: 367-376

Whitehouse MJ, Woodley VR (1987) Automated seawater nutrient analysis. British Antarctic Survey, Cambridge

Wilkinson L, Hill MA, Welná JP, Birkenbeuel GK (1992) SYSTAT for Windows: Version 5 edn. SYSTAT, Inc., Evanston, IL

Manuscript first received: January 3, 1996

Revised version accepted: May 17, 1996 